\title{
THE USE OF SEAWORM MEAL IN MATURATION DIET AS PARTIAL SUBSTITUTION OF FRESH DIET FOR POND REARED TIGER SHRIMP BROODSTOCK
}

\author{
Asda Laining", Usman, and Rachman Syah \\ Research and Development Institute for Coastal Aquaculture, Maros \\ (Received 7 November 2013; Final revised 8 September 2014; \\ Accepted 10 November 2014)
}

\begin{abstract}
The purpose of this experiment was to evaluate the effects of using seaworm meal in artificial diet as partial substitution of freshfeed for maturation of tiger shrimp. This experiment started by growing-out tiger shrimp with initial weight around $60 \mathrm{~g}$ for four months until reaching maturation phase where shrimp weight were over $90 \mathrm{~g}$ for female. Tiger shrimp was selected and stocked into 10 ton concrete tank with stocking density of 50 shrimps with ratio of female:male of $1: 1$. Dietary treatments were different levels of seaworm meal at 0\% (SW0), 10\% (SW10) and 20\% (SW20). SW0 was positive control without seaworm meal but breeder was fed with frozen seaworm. Test diets were fed as a combination of $60 \%$ test pellet and $40 \%$ fresh feed. Artificial insemination was carried out for all females before ablation to obtain fertile eggs. Results showed that after ablation, number of female matured was highest in group fed SW10 (13 breeders) and the lowest in female fed control group (7 breeders). Number of female spawned was also highest in female fed SW10 and the lowest was in positive control. Fecundity was very low in all treatments ranged from 12,00079,700 eggs/spawn. Even though female bearing spermatophore through insemination, number of spawning hatched was very low, only three spawned in each of SW0 and SW10 and two spawned in SW20. Based on number of breeders matured and spawning rate, breeder fed with SW10 gave better performance than other two diets. Technique of artificial insemination needs to be improved to increase the number of fertile eggs.
\end{abstract}

\section{KEYWORDS: polychaeta, maturation, pond-reared tiger shrimp}

\section{INTRODUCTION}

Many studies have proved that nutrition has important role in reproduction of fish and crustacea (Kanazawa, 1985; Wouters et al., 2001; Racotta et al., 2003). One of important research that has been widely applied in hatchery around the world is the utilization of several kinds of fresh feed or combination between fresh or frozen natural diet and artifi- cial diet which resulted in a better reproduction performances compared with feeding the breeder with only one type of fresh diet (Primavera et al., 1981; Chamberlain \& Lawrence, 1981; Wouters et al., 2002).

The importance of using fresh feed for maturation process of shrimp is due to the fatty acid content of those diets in particular arachidonic acid (ARA, 20:4n6), eicosapentaenoic

\footnotetext{
\# Corresponding author. Research and Development Institute for Coastal Aquaculture Jl. Makmur Dg. Sitakka No. 129, Maros 90512, Sulawesi Selatan, Indonesia. Phone: +62 411371544

E-mail: asdalaining@yahoo.com
} 
acid (EPA, 20:5n3), and docosahexanoic acid (DHA, 22:6n3) (Cavalli et al., 1997; Coman et al., 2007a). The main constraints of utilizing fresh feed in hatchery are that their nutrients contents are fluctuated and can increase the risk of bacterial and viral transmition (Harrison, 1990) specifically crustacea and seaworm. Hatcheries have already tried to apply artificial diet which majority consisted of combination of either moist or dried pellet in small portion (around 16\%) and the rest is fresh feed (Wouters et al., 2000).

Domestication of tiger shrimp carried out by CSIRO Australia was divided into two rearing phase. The first eight months was growout phase and from $8^{\text {th }}$ month to 11-12 $2^{\text {th }}$ month on was maturation phase. During maturation phase, shrimp are fed with $32.5 \%$ squid, $32.5 \%$ bivalves, $5 \%$ polychaeta combined with $30 \%$ maturation pellet (Coman et al., 2007a). Based on previous trial, it was found that combination of fresh feed and pellet diet at ratio of 40:60 resulted in a similar reproductive performances with $100 \%$ fresh feed and better performances compared with when breeder were fed with semi-moist diet (Laining et al., 2014). This indicated that during maturation stage, tiger shrimp can utilize artificial diet in large portion than fresh feed for gonad maturation process.

The role of polychaeta seaworm in reproductive system of penaeid shrimp in particular tiger shrimp is very important and it is claimed as the best feed for maturation process besides as amino acid and fatty acid sources, it is also suspected to contain active compound related to reproductive hormone (Lytle et al., 1990). Application of seaworm extract induced gonad maturation of tiger shrimp without ablation (Poltana, 2005). Several hormones have been identified in seaworm such as osmoregulatory hormone (Andreis, 2001), oxytocin/vasopressin hormone (Oumi et al., 1996 and Fujino et al., 1999), reproductive hormone (Meunpol et al., 2010), sex hormone (Hardege et al., 1994), sex pheromone (Zeeck et al., 1998) and immunehormone (Salzet, 2001).

Even though positive effect of seaworm on maturation process of crustacean has been intensively reported as a viral carrier (Meunpol et al., 2005; Binh et al., 2012), its use as a fresh feed remains to be a main problem. On the other hand, the use of seaworm meal as feed ingredient for artificial diet may reduce the viral transmission into the hatchery.
The objective of this study was to evaluate the effects of utilization of seaworm meal in artificial diet as partial substitution of fresh feed for maturation of tiger shrimp breeder in order to support domestication process both in pond and closed system tank.

\section{MATERIALS AND METHODS}

\section{Rearing of Tiger Shrimp until Maturation Stage in Earthen Pond}

This activity was conducted in experimental pond of Research and Development Institute for Coastal Aquaculture (RICA) in Laikang, Takalar, by rearing tiger shrimp with average initial body weight of $60 \mathrm{~g}$ (ranged from 40-80 g). Shrimp were stocked at around 12 months of age and the shrimp were cultured from larvae induced with faster growth marker. Shrimp were reared in $1,500 \mathrm{~m}^{2}$ earthen pond with stocking density of $1.0 \mathrm{shrimp} / \mathrm{m}^{2}$. During culture period, the shrimp were fed with commercial diet which contained around $45.4 \%$ crude protein (Table 1) enriched with vitamin $\mathrm{C}$ and carotenoid, fed at $2.5 \%$ of biomass. Shrimp were fed twice a day in the morning and afternoon. Fresh squid was fed once a week at approximately $5 \%$ of biomass in the morning. Growth was monitored every month by measuring weight and length of shrimp for four months or when female weight was $>90 \mathrm{~g}$ and male $>70$ $\mathrm{g}$ which are categorized as maturation stage. Harvest was done at this phase and shrimp then transferred to controlled tank for adaptation. During adaptation period, shrimp were selected according to desired weight, healthy condition, normal genital organ, and then checked if female bearing spermatophore.

\section{Feeding Trial for Maturation Stage in Controlled Tank}

Following trial was carried out in hatchery of tiger shrimp of RICA in Barru. Dietary treatments were two levels of seaworm (SW) meal at $10 \%$ (SW10) and 20\% (SW20). Control group was fed with diet without seaworm meal but with fresh/frozen seaworm. Diet was given according to feeding regime of $60 \%$ tested diet and $40 \%$ fresh feed. Fresh feeds being used for the feeding trial were squid and bivalves. Breeders were cultured in three tanks of $10 \mathrm{~m}^{3}$ concrete tank with stocking density of 50 shrimp/ tank and ratio of male and female was $1: 1$ (Coman et al., 2007b). Experimental diet was formulated based on previous studies on nutrient requirements for crustacean maturation 
Table 1. Proximates analysis of commersial diet used during prematuration stage in earthen pond (\%)

\begin{tabular}{lc}
\hline \multicolumn{1}{c}{ Nut rient } & Percent age (\%) \\
\hline Dry matter & 91.4 \\
Crude prote in & 45.4 \\
Lipid & 8.1 \\
Ash & 12.4 \\
Fibre & 4.3 \\
\hline
\end{tabular}

(Hoa, 2009; Marsden et al., 1997; Paibulkichakul et al., 2008; Wouters et al., 2001 b) and also based on in-house formulation that has been previously evaluated (Laining et al., 2014). During feeding trial, water was supplied as flowthrough system. Diets were given at rate of $2.5 \%$ of biomass, four times a day at 08.00 ; $12.00 ; 16.00$, and 21.00 .

For all tanks, females were eye-tagged for individual recognition and molt-tagged (water proof label glued to carapace and rubber at- tached to eye stalk) to identify when each female had molted. Molting of each female was monitored throughout trial. Females were unilaterally ablated two days after the first molt. Artificial insemination was carried out if natural mating did not happen during culture (Coman et al., 2007a).

Females were examined daily for ovarian maturation. Ripe females were transferred to $175 \mathrm{~L}$ circular spawning tanks, filled with around $150 \mathrm{~L}$ and allowed to spawn. After spawning or if the ovaries had regressed, females were weighed and returned to the maturation tanks. Fecundity per spawning was estimated from the total number of eggs collected in four $250 \mathrm{~mL}$ samples taken from the spawning tank water. Eggs were then allowed to hatch in the spawning tanks and naupli numbers per spawning were estimated with similar way of estimating the eggs number.

Biological parameters observed during maturation were survival and reproductive traits including natural gonad maturation stage of female or maturation after ablation, spawning

Table 2. Formulation of experimental diet (dried pellet, $\mathrm{g} / \mathrm{kg}$ ) with different levels of seaworm meal for maturation of tiger shrimp, $P$. monodon

\begin{tabular}{lccc}
\hline \multicolumn{1}{c}{ Ingredient s } & SW0 & SW10 & SW20 \\
\hline Anchovy fishmeal & 280 & 220 & 200 \\
Mysid meal & 160 & 180 & 130 \\
Oyster meal & 250 & 180 & 150 \\
Seaworm meal & 0 & 100 & 200 \\
Wheat gluten & 30 & 30 & 30 \\
Rice bran & 30 & 30 & 30 \\
Wheat flour & 100 & 100 & 100 \\
Fish oil & 45 & 45 & 45 \\
Soy lecithin 70\% & 15 & 15 & 15 \\
Cholesterol & 2 & 2 & 2 \\
Vitamin pre mix & 30 & 30 & 30 \\
Astaxanthine (Carophy Il pink) & 1.25 & 1.25 & 1.25 \\
Vitamin C (Stay C) & 0.57 & 0.57 & 0.57 \\
Vitamin A and D & 0.457 & 0.457 & 0.457 \\
Vitamin E & 0.2 & 0.2 & 0.2 \\
Spirulina sp. (SP Green) & 5 & 5 & 5 \\
Mineral pre mix & 30 & 30 & 30 \\
Organic mine ral & 5 & 5 & 5 \\
Attractant & 2 & 2 & 2 \\
CMC Total & 13.527 & 23.527 & 23.527 \\
\hline & 1,000 & $\mathbf{1 , 0 0 0}$ & $\mathbf{1 , 0 0 0}$ \\
\hline
\end{tabular}


rate, fecundity, and hatching rate. Observation of sperm quality was also carried out by measuring the spermatophore weight, number of spermatozoa, and number of normal and abnormal sperm. Number of sperm was calculated according to Leung-Trujillo \& Lawrence (1987). Spermatophore was homogenized using glass tissue grinder for three minutes, added with $3 \mathrm{~mL} \mathrm{Ca}^{2+}$ free saline solution and then put into haemocytometer to calculate the sperm cell under microscope. To calculate number of normal and abnormal spermatozoa, 0.1 $\mathrm{mL}$ of sperm-saline suspension was added with $0.1 \mathrm{~mL}$ trypan blue dye, kept for 5-10 min. and then calculated under microscope. Minimum cell calculated was 100 cells according to Alfaro (1993).

Proximate analysis was done according to AOAC International (1999). Fatty acid analysis of freeze dried seaworm, test diets, and gonad were carried out using Gas Chromatography (Shimadzu 2010 plus, Tokyo, Japan). Amino acid analysis of seaworm was conducted using HPLC (Shimadzu 20A, Tokyo, Japan). Data on reproductive performances were presented descriptively.

\section{RESULTS AND DISCUSSION}

\section{Fatty Acid Profile of Ingredients Used for Maturation Diet and Amino Acid Profile of Seaworm}

Fatty acid profile of seaworm and several other ingredients used for maturation diet are presented in Table 3. The EPA and DHA of squid and oyster are relatively higher than mysid and seaworm. This data was also reported in the previous experiment except for seaworm
(Laining et al., 2014). The high ARA content among ingredients were detected in seaworm and mysid around $2.82 \%$ (w/w in lipid) or $0.20 \%$ (w/w in ingredient). In addition, DHA, and EPA contents were relatively higher in all ingredients ( $w / w$ in ingredient) particularly squid and oyster compared to seaworm.

Profile of amino acid of freeze-dried seaworm is shown in Table 4. Generally, essential

Table 4. Proximate analysis and profile of amino acids of freeze-dried seaworm used in the experimental diet

\begin{tabular}{lc}
\hline \multicolumn{1}{c}{ Nutrient } & Percentage (\%) \\
\hline Moisture & 7.3 \\
Crude prote in & 52.0 \\
Lipid & 6.2 \\
Ash & 15.7 \\
Fibre & 10.8 \\
Aspartic acid & 4.82 \\
Glutamin acid & 7.49 \\
Serine & 1.79 \\
Histidine & 0.91 \\
Glycine & 2.47 \\
Threonine & 1.56 \\
Arginine & 3.07 \\
Alanine & 2.82 \\
Tyrosine & 1.38 \\
Methionine & 1.17 \\
Valine & 2.05 \\
Phenylalanine & 2.39 \\
Isole ucine & 2.11 \\
Leucine & 3.34 \\
Lysine & 2.93 \\
\hline
\end{tabular}

Table 3. Profile of fatty acids of several ingredients used in formulation of experimental diet (\% of lipid)

\begin{tabular}{lcccc}
\hline \multicolumn{1}{c}{ Type of fatty acid } & $\begin{array}{c}\text { Mysid } \\
\text { meal }\end{array}$ & $\begin{array}{c}\text { Squid } \\
\text { meal }\end{array}$ & $\begin{array}{c}\text { Seaworm } \\
\text { meal }\end{array}$ & $\begin{array}{c}\text { Oyster } \\
\text { meal }\end{array}$ \\
\hline Fat content & 2.61 & 7.54 & 7.22 & 9.36 \\
\hline Fatty acid: & & & & \\
- Linoleic Acid, C18:3n6 (LOA) & 1.59 & 6.87 & 1.28 & 1.08 \\
- Linolenic Acid, C1 8:3n3 (LNA) & 1.37 & 2.52 & 0.74 & 0.14 \\
- Arachidonic Acid, C20:4n6 & 3.57 & 0.62 & 2.82 & 1.97 \\
- Eicosapentaenoic Acid, C20:5n3 & 8.81 & 8.44 & 1.61 & 5.45 \\
- Docosahexaenoic Acid, C22:6n3 & 14.85 & 12.67 & 0.14 & 9.73 \\
\hline
\end{tabular}


amino acid content of seaworm was lower than anchovy meal but relatively similar to commercial brown fish meal (Hertrampf and PiedadPascual, 2000).

\section{Fatty Acid Profile of Maturation Diets Used for Feeding Trial}

Profile of fatty acids of maturation diets based on analysis are presented in Table 5 . Concentration of linoleic and linolenic acid were relatively similar among test diets in a range of $0.31 \%-0.37 \%$ and $0.09 \%-0.10 \%$, respectively. Similarly, EPA and DHA content were also the same among diets, however detected EPA level of the three diets $(0.49 \%-0.56 \%)$ was lower than estimated. Concentration of ARA increased (0.16\%-0.28\%) as inclusion of seaworm meal in diet increased. Other nutrients required for maturation process such as vitamin and astaxanthine were also included in the diet at the same level.

\section{Growth of Tiger Shrimp Reared in Earthen Pond}

Survival rate of tiger shrimp after 120 days culture in pond was $55 \%$ and weight gain was
34.3\%. Growth pattern during the culture is described in Figure 1. It showed that even though age of shrimp at stocking were already around 12 months its growth was still linear (Figure 1).

However, at the end of culture when shrimps were around 16 months of age, its stagnant growth was indicated by lower weight gain around $30 \%$. In nature, shrimp grow rapidly until 9 months of age and then stagnant (Rothlisberg, 1998). Even though shrimp at harvest reaching 16 months of age, the survival rate was still high probably due to the positive effect of pellet with $45.4 \%$ crude protein combined with small part of fresh feed. Relatively higher survival rate obtained during pond culture also indicated that stocking density of 1 shrimp $/ \mathrm{m}^{2}$ was suitable for rearing tiger shrimp until maturation stage.

Further assessment showing that no female shrimp beared spermatophore in the thelicum when transferred to the maturation tank, implying that natural mating did not happen during culture in pond. This indicated that male shrimp can not spawn in pond environment. Coman et al. (2007a) reported that after feed-

Table 5. Nutrient composition of the test diets applied during maturation trial (\%)

\begin{tabular}{|c|c|c|c|}
\hline Nut rient & swo & SW10 & SW20 \\
\hline Dry matter & 91.9 & 91.5 & 91.0 \\
\hline Crude prote in & 46.7 & 46.5 & 46.0 \\
\hline Lipid & 9.4 & 9.7 & 9.9 \\
\hline Ash & 12.1 & 11.7 & 11.5 \\
\hline Fibre & 2.1 & 3.1 & 4.0 \\
\hline Energy $(\mathrm{GE}, \mathrm{MJ} / \mathrm{kg})^{*}$ & 17.5 & 16.6 & 16.0 \\
\hline LOA (1 8: 2n-6) & 0.31 & 0.37 & 0.33 \\
\hline LNA (1 8:3n-3) & 0.09 & 0.10 & 0.09 \\
\hline ARA $(20: 4 n-6)$ & 0.15 & 0.17 & 0.28 \\
\hline $\operatorname{EPA}(20: 5 n-3)$ & 0.56 & 0.56 & 0.49 \\
\hline DHA (22:6n-3) & 1.19 & 1.14 & 0.9 \\
\hline Total $n-3$ & 1.90 & 1.81 & 1.54 \\
\hline Total n-6 & 0.62 & 0.57 & 0.52 \\
\hline Ratio n3/n6 & 3.06 & 3.18 & 2.96 \\
\hline Total phospholipid" & 2.82 & 2.63 & 2.46 \\
\hline Chole ste rol $^{*}$ & 0.31 & 0.32 & 0.30 \\
\hline Vitamin $C^{*}$ & 0.2 & 0.2 & 0.2 \\
\hline Vitamin $\mathrm{E}^{*}$ & $100 \mathrm{mg} / \mathrm{kg}$ & $100 \mathrm{mg} / \mathrm{kg}$ & $100 \mathrm{mg} / \mathrm{kg}$ \\
\hline Astaxanthin" & $106 \mathrm{mg} / \mathrm{kg}$ & $105.4 \mathrm{mg} / \mathrm{kg}$ & $104.2 \mathrm{mg} / \mathrm{kg}$ \\
\hline
\end{tabular}

"Values were estimated by nutrient content of each ingredient used database in a feed formulator 


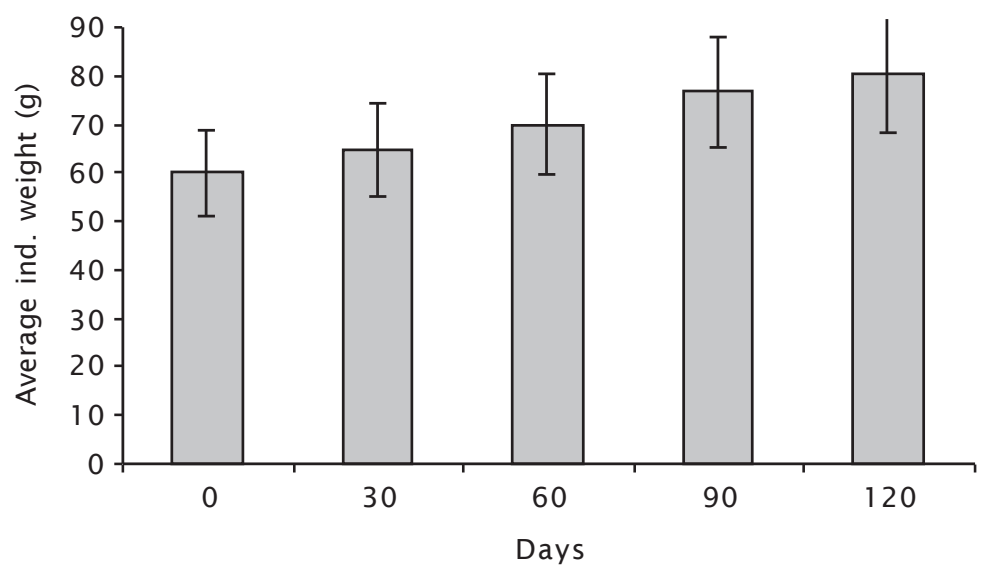

Figure 1. Average individual weight of tiger shrimp during 120 days reared in earthen pond

ing with two combination maturation diets, it was found only one out of 17 female of $2^{\text {nd }}$ generation of tiger shrimp that matured naturally. It was fed with control diet consisting of $32.5 \%$ squid, $32.5 \%$ bivalves, $5 \%$ polychaetes (Marphysa sp.), and 30\% pellet diet since shrimp aged 10 months until reproductive assessment held. These two findings indicated that low mating rate was still remain a problem in domestication of tiger shrimp both in pond and controlled tank (Coman et al., 2007a).

\section{Reproductive Performances of Tiger Shrimp}

Weight gain of female broodstock and survival rate of all broodstocks after four months feeding trial of maturation stage were presented in Table 6. Weight of female at the end of feeding trial increased little bit or even stagnant ranging from $3.8 \%$ to $8.4 \%$. At this time, female broodstocks were around 20 months of age. Survival rate of broodstock (calculated for all female and male broodstock) was from
$66 \%-70 \%$, it showed that broodstock can survive longer in controlled tank if nutrition and other environment factors were in proper condition. This also indicated that at maturation stage, tiger shrimp broodstock can be reared longer without sand-bottom substrate.

Reproductive performances of pond reared breeders are presented in Table 7. During acclimatization and before ablation, no breeder matured naturally. Number of broodstock matured after ablation was the highest in group fed SW1 0 (13 breeders) and the lowest was in broodstock fed SW0 (7 breeders). Number of spawning was also the highest in group fed SW1 0 and lowest in SW0. All groups had lower fecundity ranged from around 12,000 to 79,000 eggs/spawn. Since none of female beared spermatophore during rearing period in pond, all females were artificially inseminated to produce fertile eggs. However, number of spawn that hatched was very low only three spawning for each of SW 0 and SW1 0 and two spawning in SW20. Total nauplii (F2) of each

Table 6. Weight and survival rate of pond reared shrimp phase during four months maturation period in controlled tank

\begin{tabular}{lccc}
\hline \multicolumn{1}{c}{ Paramet ers } & Sw0 & Sw10 & SW20 \\
\hline Initial ind. weight of male $(\mathrm{g})$ & $73(\mathrm{n}=25)$ & $75(\mathrm{n}=25)$ & $73(\mathrm{n}=25)$ \\
Initial ind. weight of fe male $(\mathrm{g})$ & $106(\mathrm{n}=25)$ & $107(\mathrm{n}=25)$ & $106(\mathrm{n}=25)$ \\
Final ind. weight of female $(\mathrm{g})$ & 110 & 116 & 113 \\
Weight gain of fe male (\%) & 3.8 & 8.4 & 6.6 \\
Survival rate (male and fe male, \%) & 70 & 66 & 70 \\
\hline
\end{tabular}


Table 7. Reproductive performance of pond reared shrimp phase maturation fed different levels of seaworm meal

\begin{tabular}{lccc}
\hline \multicolumn{1}{c}{ Paramet ers } & SW0 & SW10 & SW20 \\
\hline No. of naturally matured stock & 0 & 0 & 0 \\
No. of breeder maturing after ablation & $7(\mathrm{n}=24)$ & $13(\mathrm{n}=24)$ & $11(\mathrm{n}=24)$ \\
No. of breeder spawned per ablated stock & 6 & 11 & 9 \\
Range of fecundity (eggs/bre eder) & $12,300-79,700$ & $12,500-67,165$ & $14,000-65,500$ \\
No. of spawning that hatched (inse minated) & 3 & 3 & 2 \\
Total nauplii/tank (larvae/tank) & $56,483(\mathrm{n}=3)$ & $19,945(\mathrm{n}=3)$ & $2,990(\mathrm{n}=2)$ \\
No. of 2 & & 3 & 6 \\
\hline
\end{tabular}

tank were only around 56,000 larvae found in SW0 and 19,900 larvae in SW10.

Performances of male breeder at the end of feeding trial are shown in Table 8 . Weight of spermatophore obtained by electrical shock was relatively similar among groups ranged from 0.04-0.05 g. Number of sperm per spermatophore was the highest at fish fed SW10, while shrimp fed SW20 had relatively similar sperm cell. Number of normal sperms ranged from around 70-78 (x 106 cells/spermatophore) which were relatively similar among groups. On the other hand, number of abnormal sperm ranged from 22 to 30 ( $\times 10^{6}$ cells/spermatophore).

Low natural mating rate found in this trial and other studies showed that mating rate remains the main constrain in domesticated tiger shrimp to produce broodstock. Hoa (2009) reported $17 \%-22 \%$ natural mating rate of tank reared domesticated tiger shrimp breeder which was relatively high that compared to what CSIRO domesticated team reported (Comen et al., 2005) and compared to the present trial which no natural mating found during the feeding period. Even though artificial insemination was carried out for all survived females, very low fertile eggs obtained in this trial implied that only few inseminated females could fertilize their eggs. Techniques of insemination applied on this trial needs to be modified to increase number of fertile eggs.

Low fecundity found in this trial was in the range of eggs fecundity of domestiscated tiger shrimp reported by other works. Comen et al. (2005) found that egg fecundity of several families of pond reared tiger shrimp breeder ranged from 56,260-167,710 eggs/broodstock, 11-17 months of age. These shrimps were fed with combination diets consisting of $20 \%$ squid, $5 \%$ bivalves, and $70 \%$ high protein pellet until eight months of age and from 8 to 11 months of age fed with $30 \%$ squid, $20 \%$ mussels, and $5 \%$ polychaetes combined with $45 \%$ pellet.

Domesticated tiger shrimp reported by Hoa (2009) showed a variety of egg fecundity ranged from 60,000-617,000 eggs/spawning with average of 309,630 eggs. Maturation diets that were applied on their study were also

Table 8. Reproductive performance of pond reared male maturation phase fed different levels of seaworm meal

\begin{tabular}{lccc}
\hline \multicolumn{1}{c}{ Paramet ers } & SW0 & SW10 & SW20 \\
\hline Weight of male (g) & 87.2 & 74.4 & 72.0 \\
Age of male breeder (months) & 20 & 20 & 20 \\
Weight of spermatophore $(\mathrm{g})$ & $0.05(\mathrm{n}=4)$ & $0.04(\mathrm{n}=4)$ & $0.05(\mathrm{n}=3)$ \\
No. of sperm/spermatophore $\left(\right.$ cell $\left.\times 10^{6}\right)$ & 63.8 & 91.5 & 66.8 \\
No. of normal sperm (cell x 106) & 75.5 & 78.1 & 69.7 \\
No. of abnormal sperm (\%) & 24.5 & 21.9 & 30.3 \\
\hline
\end{tabular}




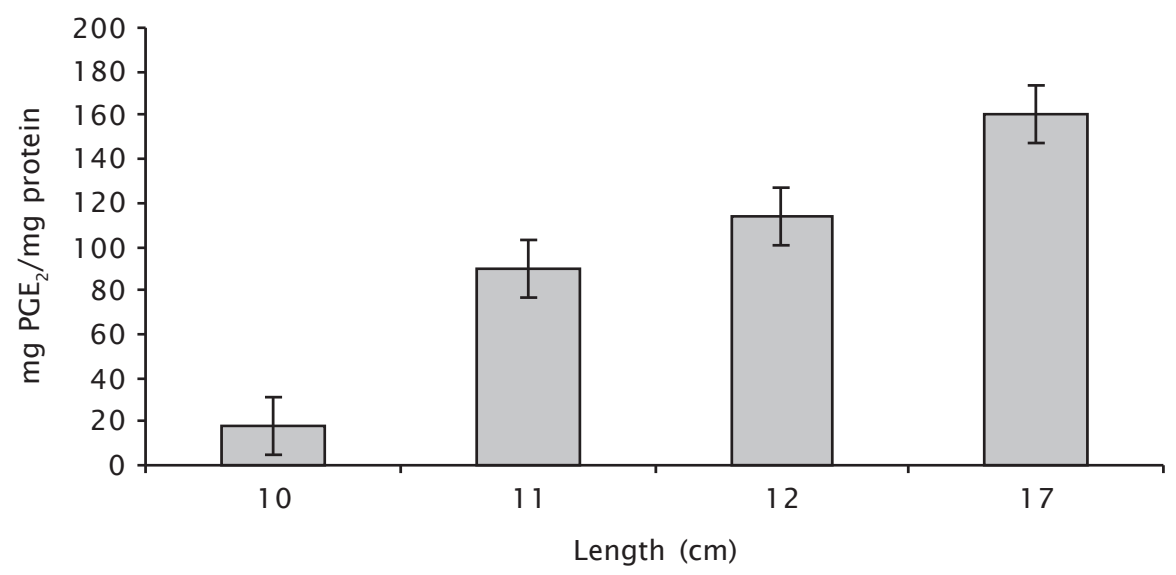

Figure 2. Levels of prostaglandin $E_{2}\left(P E_{2}\right)$ measured in natural sand polychaetes, Perinereis sp. at size differences (Meunpol et al., 2010)

combination between $40 \%$ fresh feed $37 \%$ squid, $27 \%$ oyster, $17 \%$ seaworm, and $19 \%$ pig liver) and $60 \%$ pellet.

Among natural fresh feed that were extensively used for gonadal maturation and spawning of penaeid shrimp, the best is squid and polychaete seaworm (Yano, 2000; Meunpol et al., 2005). The role of these two diets on the reproductive process has not been fully understood, but many studies reported that squid and seaworm are rich in fatty acids content such as n-3 HUFA and PUFA specifically EPA, DHA, dan ARA (Wouters et al., 2001 a dan Racotta et al., 2003). This is in line with fatty acid analysis of main ingredients used in this trial which confirmed the high EPA and DHA in squid and high ARA content in seaworm meal. Besides their fatty acids content, marine polychaetes also contained some sexual steroids hormones such as $17 \beta$-estradiol, progesterone, prostaglandin in Nereis virens (Garcia-Alonso \& Rebscher, 2005), Nereis diversolor (Mouneyrac et al., 2006). Recent studies reported that Perinereis sp. contained several reproductive hormones including progesterone which were effective in enhancing the final maturation and $17 \alpha$-OHP4 had more effects on vitellogenic oocytes (Meunpol et al., 2007). Moreover, prostaglandin $E_{2}\left(P G E_{2}\right)$ was also detected in polychaete as shown in Figure 2 which enhanced oocytes development especially during late development and ovulation (Meunpol et al., 2010).

Steroid-like hormones in marine polychaetes also possess some amines and/or neuro- peptides including osmoregulatory hormone, sex pheromones (Hardege et al., 2004), oxytocins involved in regulating reproductive functions such as mating recognition and gamete release (Andries, 2001). Binh et al. (2012) tried to extract polychaete into different fractions and found that polychaete extract in form of NLF (neutral lipid fraction) gave the most effective fraction on ovarian maturation of Marsupenaues japonicus broodstock and followed by TSF (trichloroacetic acid soluble extract). They assumed that NLF contains some active substances for ovarian maturation and TSF may contain these polychaete amines/ neuropeptides that might be directly or indirectly involved in sexual maturation of $M$. japonicus.

\section{CONCLUSION}

Based on number of matured female and spawned female as well as male reproductive performances, it is concluded that $10 \%$ of seaworm meal was enough to be included in maturation diet. Artificial insemination is highly required to allow more assessment of reproductive performances in order to evaluate the effect of maturation diet on tiger shrimp breeder.

\section{REFERENCES}

Alfaro, J.M. (1993). Reproductive quality evaluation of male Penaeus stylirostris from a grow-out pond. J. World Aquac. Soc., 24(1), 6-11.

Garcia-Alonso, J., \& Rebscher, N. (2005). Estra- 
diol signalling in Nereis viren reproduction. Invertebrate Reproduction Dev., 48, 95-100.

Andreis, J.C. (2001). Endocrine and environmental control ofreproduction in polychaete. Canadian Journal of Zoology, 79, 254-270.

AOAC International. (1999). Official methods of analysis. $16^{\text {th }}$ eds. Association of Official Analytical Chemists International, Gaithersberg, Maryland. USA, 1141 pp.

Binh, T.N., Koshio, S., Sakiyama, K., Ishikawa, M., Yokoyama, S., \& Kader, A. (2012). Effects of polychaete extracts on reproductive performance of kuruma shrimp, Marsupenaus japonicus Bate. Part Il. Ovarian maturation and tissue lipid composition. Aquaculture, 334-337, 65-72.

Cavalli, R.O., Scardua, M.P., \& Wasielesky, W.J. (1997). Reproductive performance of different-sized wild and pond-reared Penaeus paulensis females. J. World Aquaculture Society, 28, 260-267.

Chamberlain, G.W., \& Lawrence, A.L. (1983). Reproductive activity and biochemical composition of Penaeus setiferus and Penaeus aztecus in the Gulf of Mexico. Texas A \& M University, Sea Grant College Program Report No. TAMU-SG-84-203, 35 pp.

Coman, G.J., Crocos, P.J., Arnold, S.J., Keys, S.J., Murphy, B., \& Preston, N.P. (2005). Growth, survival and reproductive performance of domesticated Australian stocks of the giant tiger prawn, Penaeus monodon reared in tanks and raceways. J. World of Aquaculture Soc., 36, 464-479.

Coman, G.J., Arnold, S.J., Callaghan, T.R., \& Preston, N.P. (2007a). Effect of two maturation diet combinations on reproductive performance of domesticated Penaeus monodon. Aquaculture, 263, 75-83.

Coman, G.J., Arnold, S.J., Jones, M.J., \& Preston, N.P. (2007b). Effect of rearing density on growth, survival and reproductive performance of domesticated Penaeus monodon. Aquaculture, 264, 175-183.

Fujino, Y., Nagahama, T., Oumi, T., Ukena, K., Morishita, F., Furukawa, Y., Matsushima, O., Ando, M., Takahama, H., Satake, H., Minakata, H., \& Nomoto, K. (1999). Possible functions of oxytocin/vasopress in super family peptides in annelids with special reference to reproduction and osmoregulation. J. Experimental Zoology, 284(4), 401406.

Hardege, J.D., Bartel-Hardege, H.D., Yang, Y., Wu, B.L., Zhu, M.Y., \& Zeek, E. (1994). Envi- ronmental control of reproduction of Perinereis nuntia var. brevicirrus. J. Mar. Biol. Assoc. U.K., 74, 903-918.

Harrison, K.E. (1990). The role of nutrition in maturation, reproduction and embryonic development of decapod crustaceans: a review. J. of Shellfish Res., 9, 1-28.

Hertrampf, J.W., \& Piedad-Pascual, F. (2000). Handbook on ingredients for aquaculture feeds. Kluwer Academic Press. The Netherland, $573 \mathrm{pp}$.

Hoa, N.D. (2009). Domestication of black tiger shrimp (Penaeus monodon) in recirculation systems in Vietnam. Ph.D. thesis, Ghent University. Belgium, 189 pp.

Kanazawa, A. (1985). Nutrition of penaeid prawn and shrimps. In Taki, Y., Primavera, J.H., \& Llobrera, J.A. (Eds.), Proceeding of the First International Conference on the Culture of Penaeid Prawn/Shrimp. Aquaculture Department, Southeast Asian Fisheries Development Center, Iloilo. Philippines, p. 123130.

Laining, A., Usman, \& Muslimin. (2014). Growth and reproductive performances of pond reared tiger shrimp, Penaeus monodon, fed different combinations of maturation diets. Indonesian Aquaculture Journal, 9(1), 6777.

Leung-Trujillo, J.R., \& Lawrence, A.L. (1987). Observations on the decline in sperm qualityof Penaeus setiferus under laboratory conditions. Aquaculture, 65, 363-370.

Lytle, J.S., Lytle, T.F., \& Ogle, J. (1990). Polyunsaturated fatty acid profiles as a comparative tool in assessing maturation diets of Penaeus setiferus. Aquaculture, 89, 287299.

Marsden, G.E., McGuren, J.J., Hansford, S.W., \& Burke, M.J. (1997). A moist artificial diet for prawn broodstock: its effect on the variable reproductive performance of wild caught Penaeus monodon. Aquaculture, 149, 145-156.

Meunpol, O., Duangjai, E., Yoopun, R., \& Piyatiratitivorakul, S. (2005). Determination of prostaglandin $E_{2}\left(P E_{2}\right)$ in polychaetes (Perinereis sp.) and its effect on Penaeus monodon oocytes development in vitro. In Book of short communication, Larvi 2005, Ghent University. Belgium, p. 320323.

Meupol, O., Iam-Pai, S., Suthikrai, W., \& Piyatiratitivorakul, S. (2007). Identification of progesterone and $17 \alpha$-hydroxyproges- 
terone in polychaetes (Perinereis sp.) and the effects of hormone extracts on penaeid oocyte development in vitro. Aquaculture, 270, 485-492.

Meunpol, O., Duangjai, E., Yoopun, R., \& Piyatiratitivorakul, S. (2010). Detection of prostaglandin $\mathrm{E}_{2}$ in polychaetes Perinereis sp. and its effect on Penaues monodon oocytes development in vitro. Fisheries Science, 76, 281-286.

Mouneyrac, C., Pellerin, J., Moukrim, A., AitAlla, A., Durou, C., \& Viault, N. (2006). In situ relationship between energy reserves and steroid hormone levels in Nereis diversicolor (O.F. Müller) from clean and contaminated sites. Ecotoxicology and Environmental Safety, 65, 181-187.

Oumi, T., Ukena, K., Matsushima, O., Ikeda, T., Fujita, T., Minakata, H., \& Nomoto, K. (1996). Annetocin, an annelid oxytocin-related peptide, induces egg-laying behavior in the earthworm, Eisenia foetida. J. Experimental Zoology, 276(2), 151-156.

Paibulkichakul, C., Piyatiratitivorakul, S., Sorgeloos, P., \& Menasveta, P. (2008). Improved maturation of pond-reared, black tiger shrimp (Penaeus monodon) using fish oil and astaxanthin feed supplements. Aquaculture, 282(1-4), 83-89.

Poltana, P. (2005). Morphological development of the polychaete Perenereis nuntia and the effect of its hormonal extracts on ovarian maturation in Penaeus monodon that do not undergo eyes talk ablation. Ph.D. Thesis Abstract, Mahidol University. Thailand.

Primavera, J.H., \& Posadas, R.A. (1981). Studies on the egg quality of Penaeus monodon fabricus, based on morphology and hatching rate. Aquaculture, 22, 269-277.
Racotta, I.S., Palacios, E., \& Ibarra, A.M. (2003). Shrimp larval quality in relation to broodstock condition. Aquaculture, 227, 107-130.

Rothlisberg, P.C. (1998). Aspects of penaeid biology and ecology of relevance to aquaculture: a review. Aquaculture, 164, 4965.

Salzet, M. (2001). The neuroendo crinology systems of annelids. Can. J. Zoology, 79, 175-191.

Wouters, R., Nieto, J., \& Sorgeloos, P. (2000). Artificial diets for penaeid shrimp. Global Aquaculture Advocate, 3, 61-62.

Wouters, R., Lavens, P., Nieto, J., \& Sorgeloos, P. (2001 a). Penaeid shrimp broodstock nutrition: an updated review on research and development. Aquaculture, 202, 1-21.

Wouters, R., Piguave, X., Bastidas, L., \& Sorgeloos, P. (2001 b). Ovarian maturation and haemolymphatic vitellogenin concentration of Pacific white shrimp Litopenaeus vannamei (Boone) fed increasing levels of total dietary lipids and HUFA. Aquaculture Research, 32, 573-582.

Wouters, R., Zambrano, B., Espin, M., Calderol, J., Lavens, P., \& Sorgeloos, P. (2002). Experimental broodstock diets as partial fresh food substitutes in white shrimp Litopenaeus vannamei B. Aquaculture Nutrition, 8, 249-256.

Yano, I. (2000). Endocrine control of reproductive maturation in economically important crustacea for aquaculture. In Adiyodi, K.G., \& Adiyodi, R.G. (Eds.), Reproductive Biology of Invertebrate. Wiley. New York, p. 161194.

Zeeck, E., Harder, T., \& Beckmann, M. (1998). Uric acid: the sperm release pheromone of the marine polychaete Platynereis dumerilii. J. Chem. Ecology, 24(1), 13-22. 